Asian J. Med. Biol. Res. 2019, 5 (4), 280-285; doi: 10.3329/ajmbr.v5i4.45265

\author{
Asian Journal of \\ Medical and Biological Research \\ ISSN 2411-4472 (Print) 2412-5571 (Online) \\ www.ebupress.com/journal/ajmbr
}

\title{
Article \\ Health promoting pigments and bioactive compounds of six vegetables grown in Bangladesh
}

Rowshon Sultana ${ }^{1}$, Mohammed Arif Sadik Polash ${ }^{1}$, Md. Arif Sakil ${ }^{2}$, Shagata Islam Shorna ${ }^{1}$, Md. Shahidur Rahman $^{1}$, Md. Atikur Rahman ${ }^{3}$, Md. Abdul Hakim ${ }^{1}$ and Md. Alamgir Hossain ${ }^{1 *}$

${ }^{1}$ Plant Physiology Lab, Department of Crop Botany, Bangladesh Agricultural University, Mymensingh-2202, Bangladesh

${ }^{2}$ Food Biochemistry Lab, Department of Biochemistry and Molecular Biology, Bangladesh Agricultural University, Mymensingh-2202, Bangladesh

${ }^{3}$ Department of Plant Pathology, Bangladesh Agricultural University, Mymensingh-2202, Bangladesh

*Corresponding author: Professor Dr. Md. Alamgir Hossain, Plant Physiology Lab, Department of Crop Botany, Bangladesh Agricultural University, Mymensingh-2202, Bangladesh. E-mail: alamgir.cbot@ bau.edu.bd

Received: 12 September 2019/Accepted: 16 October 2019/ Published: 31 December 2019

\begin{abstract}
Increasing of chronic diseases due to low consumption of vegetables considered one of the crucial challenges to human being in current circumstance. Adequate intake of vegetables only the possible solution from get rid of the problem. So it is indispensible to determine food value present in vegetables which were the core objective of our present study. Among the tested vegetables beetroot showed the highest nitrate content $\left(874 \mathrm{mg} \mathrm{Kg}^{-1}\right.$ ) whereas the lowest nitrate content was found in bitter gourd (56 $\mathrm{mg} \mathrm{Kg}^{-1}$ ). Total chlorophyll

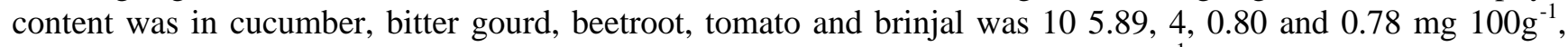
respectively. The highest carotene contain was found in cucumber $\left(1.63 \mathrm{mg} 100 \mathrm{~g}^{-1}\right)$. Beetroot, tomato, brinjal and bitter gourd showed reduction in carotene content at $61.96,71.16,87.73$ and $97.71 \%$, respectively in response to cucumber. Lycopene content was the highest in beetroot $\left(3.46 \mathrm{mg} 100 \mathrm{~g}^{-1}\right)$ and the lowest in brinjal

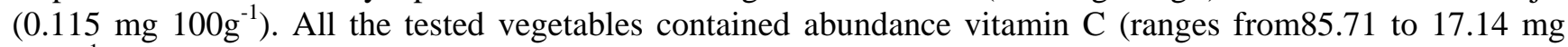
$\left.100 \mathrm{~g}^{-1}\right)$. DPPH radical scavenging activity was present in all tested vegetables in which beetroot exhibited the highest DPPH radical scavenging activity with an $\mathrm{IC}_{50}$ value of $1.17 \mu \mathrm{gml}^{-1}$.
\end{abstract}

Keywords: anti-oxidant properties; bioactive compounds; cardio-protective molecule; vegetables; vitamin C

\section{Introduction}

Inadequate dietary intake of vegetables leads cardio-vascular and ROS related diseases (Miller and Welch, 2013) which is becoming major public health problem and insert a serious headache to health professionals in Bangladesh. Mamun et al. (2016), reported, about $95.7 \%$ people are deprived of consuming adequate fruits and/or vegetables in Bangladesh. In this context, vegetables were highlighted as a potential candidate for ROS and cardio protection (Alissa and Ferns, 2017; Sakil et al., 2018; Polash et al., 2018). Vegetables are essential to human health since they are good source of nitrate, vitamins, minerals and biologically active substances (Alarcon-Flores et al., 2014; Sakil et al., 2018; Polash et al., 2019). So, WHO stressed to increase the consumption of vegetables since they are the fundamental components of a healthy diet (WHO, 2005). In spite of conferring with plenty of green vegetables around and almost everywhere there is no proper scientific data about cardiovascular molecule, bioactive compounds and anti-oxidant properties of popular vegetables. Therefore, the current research work was designed to determine cardiovascular molecule, bioactive compounds and anti-oxidant properties of some popular vegetables. 


\section{Materials and Methods}

Cucumber, beetroot, tomato, eggplant and bitter gourd (which were selected by sensory attribute test according to Xiao et al., 2015b) were the experimental materials of this study which were collected at maturity from local market of Mymensingh, Bangladesh. The experiment was conducted in Plant Physiology Lab, Department of Crop Botany and Food Biochemistry Lab, Department of Biochemistry and Molecular Biology from November 2018 to March 2019. Each test was replicated with three times for more accuracy.

\subsection{Determination of nitrate $\left(\mathrm{NO}_{3}{ }^{-}\right)$content}

Nitrate content of cucumber, beetroot, bitter gourd, eggplant and tomato were determined by portable nitrate detector named 'greentest Eco'. The total nitrate content was expressed by $\mathrm{mgKg}^{-1}$ fresh weight. The lower limit of detection (LOD) of nitrate ions by the detector is $4 \mathrm{mg} \mathrm{Kg}^{-1}$.

\subsection{Bioactive compounds assessment}

The fleshy edible part of plants $(6.67 \mathrm{~g})$ was extracted in $10 \mathrm{ml}$ of chilled acetone solution in dark. After centrifugation at $4000 \mathrm{rpm}$ for 10 minutes the absorbance of supernatants was taken at 453, 505, 645 and 663 $\mathrm{nm}$ wave length. Contents were calculated according to the equation depicted in Barros et al. (2010), and

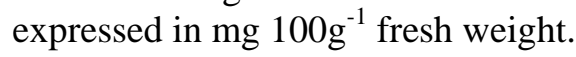

\subsection{Vitamin $C$ content in tested vegetables}

Ascorbic acid was determined following a procedure previously described by the authors Xaio et al. (2012), with 2.6-dichloroindophenl and measuring the content by titrimetric method. The results were expressed as $\mathrm{mg}$ of ascorbic acid per $100 \mathrm{~g}$ of fresh weight.

\subsection{DPPH radical scavenging activity}

1,1-diphenyl-2-picrylhydrazyl (DPPH) assay is carried out with some modifications of Sanja et al. (2009). DPPH radical scavenging activity is measured by reduction in intensity of purple color and quantified by decrease in absorbance at wavelength $517 \mathrm{~nm}$. Radical scavenging activity was calculated using the following formula:

Here, $\mathrm{OD}=$ Optical density

$$
\% \text { radical scavenging activity }=\frac{\text { OD of control-OD of sample }}{\text { OD of control }} \times 100
$$

\subsection{Statistical analysis}

The collected data were statistically analyzed by using Minitab 17. Fishers LSD test was applied to compare the treatment means at 0.05 level of confidence.

\section{Results}

\subsection{Nitrate $\left(\mathrm{NO}_{3}{ }^{-}\right)$content}

All tested vegetables contained nitrate (Figure 1). Here beetroot showed the highest nitrate content $(874 \mathrm{mg} \mathrm{Kg}$

$\left.{ }^{1}\right)$ followed by Cucumber $\left(94 \mathrm{mg} \mathrm{Kg}^{-1}\right)$. Tomato and brinjal showed nitrate content at 82 and $80 \mathrm{mg} \mathrm{Kg}^{-1}$, respectively. The lowest nitrate content was found in bitter gourd $\left(56 \mathrm{mg} \mathrm{Kg}^{-1}\right)$ (Figure 1).

\subsection{Chlorophyll content}

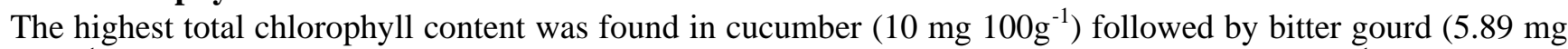
$\left.100 \mathrm{~g}^{-1}\right)$. Beetroot, tomato and brinjal contained total chlorophyll at $4,0.80$ and $0.78 \mathrm{mg}^{100 \mathrm{~g}^{-1}}$, respectively. Among the tested vegetables, chlorophyll a was always higher than chlorophyll $b$ (Table 1).

\subsection{Carotene content}

In case of carotene, a significant difference was found in the tested vegetables (Figure 2). The highest carotene

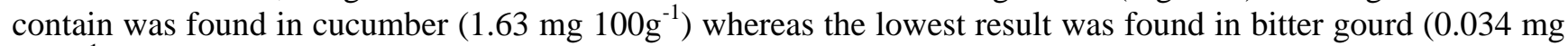
$100 \mathrm{~g}^{-1}$ ). Beetroot, tomato and brinjal showed reduction in carotene content at $61.96,71.16$ and $87.73 \%$, respectively in response to cucumber (Figure 2). 


\subsection{Lycopene content}

The highest lycopene content $\left(3.46 \mathrm{mg}_{100 \mathrm{~g}^{-1}}\right)$ was found in beetroot followed by tomato $\left(1.96 \mathrm{mg} 100 \mathrm{~g}^{-1}\right)$. The lycopene content of cucumber, bitter gourd and brinjal was $0.205,0.166$ and $0.115 \mathrm{mg}_{100 \mathrm{~g}^{-1}}$, respectively (Figure 3).

\subsection{Vitamin $\mathrm{C}$ content}

All the tested vegetables contained vitamin $\mathrm{C}$ in abundance (Figure 4). The highest vitamin $\mathrm{C}$ content was found

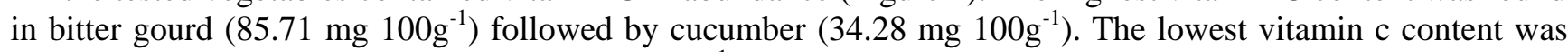

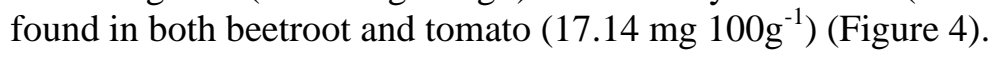

\subsection{DPPH radical scavenging activity}

Among tested vegetables beetroot exhibited the highest radical scavenging activity with an $\mathrm{IC}_{50}$ value of $1.17 \mu \mathrm{g}$ $\mathrm{ml}^{-1}$. Moderate radical scavenging activity was shown by tomato whose $\mathrm{IC}_{50}$ value was $2.17 \mu \mathrm{g} \mathrm{ml}^{-1}$. Cucumber showed the lowest radical scavenging activity with an $\mathrm{IC}_{50}$ value $3.26 \mu \mathrm{g} \mathrm{ml}^{-1}$ (Figure 5). The lowest $\mathrm{IC}_{50}$ value means had the highest anti-oxidant capacity (Figure 5).

Table 1. Chlorophyll a, chlorophyll $b$ and total chlorophyll of the edible part of some dainty vegetables at maturity.

\begin{tabular}{llll}
\hline Vegetables & $\begin{array}{l}\text { Chlorophyll a } \\
\left(\mathbf{m g ~ 1 0 0 g}^{-1}\right)\end{array}$ & $\begin{array}{l}\text { Chlorophyll b } \\
\left(\mathbf{m g ~ 1 0 0 ~}^{-1}\right)\end{array}$ & $\begin{array}{l}\text { Total Chlorophyll } \\
\left(\mathbf{m g ~ 1 0 0 g ^ { - 1 }}\right)\end{array}$ \\
\hline Cucumber & $8.35 \pm 0.35 \mathrm{a}$ & $1.97 \pm 0.19 \mathrm{~b}$ & $10.32 \pm 0.415 \mathrm{a}$ \\
Beetroot & $2.48 \pm 0.18 \mathrm{c}$ & $1.9 \pm 0.11 \mathrm{~b}$ & $4.38 \pm 0.21 \mathrm{~b}$ \\
Tomato & $0.46 \pm 0.03 \mathrm{~d}$ & $0.344 \pm 0.02 \mathrm{c}$ & $0.804 \pm 0.04 \mathrm{c}$ \\
Bitter gourd & $3.66 \pm 0.18 \mathrm{~b}$ & $2.23 \pm 0.15 \mathrm{a}$ & $5.89 \pm 0.19 \mathrm{~b}$ \\
Brinjal & $0.452 \pm 0.02 \mathrm{~d}$ & $0.329 \pm 0.01 \mathrm{c}$ & $0.781 \pm 0.04 \mathrm{c}$ \\
\hline
\end{tabular}

The values represent the mean \pm SE (Standard Error). Values marked with the same letter within the columns do not differ significantly @ 5\% level of probability.

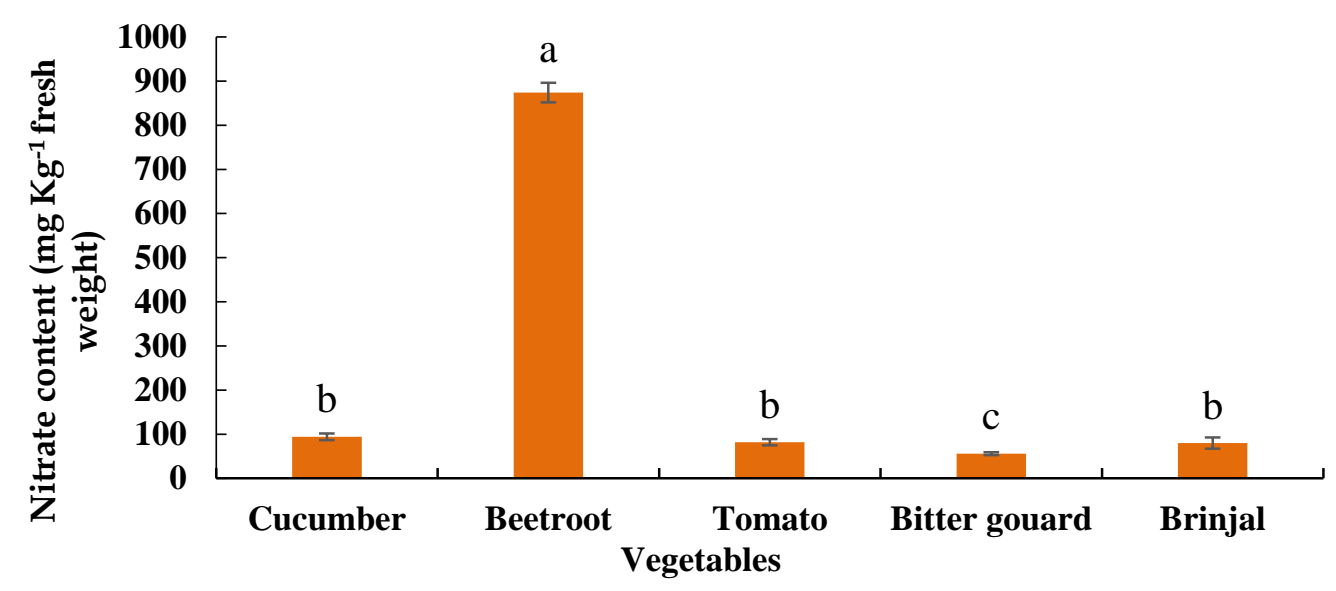

Figure 1. Nitrate content of the edible part of some dainty vegetables at maturity stage. The vertical bars represent the mean \pm SE (Standard Error). 


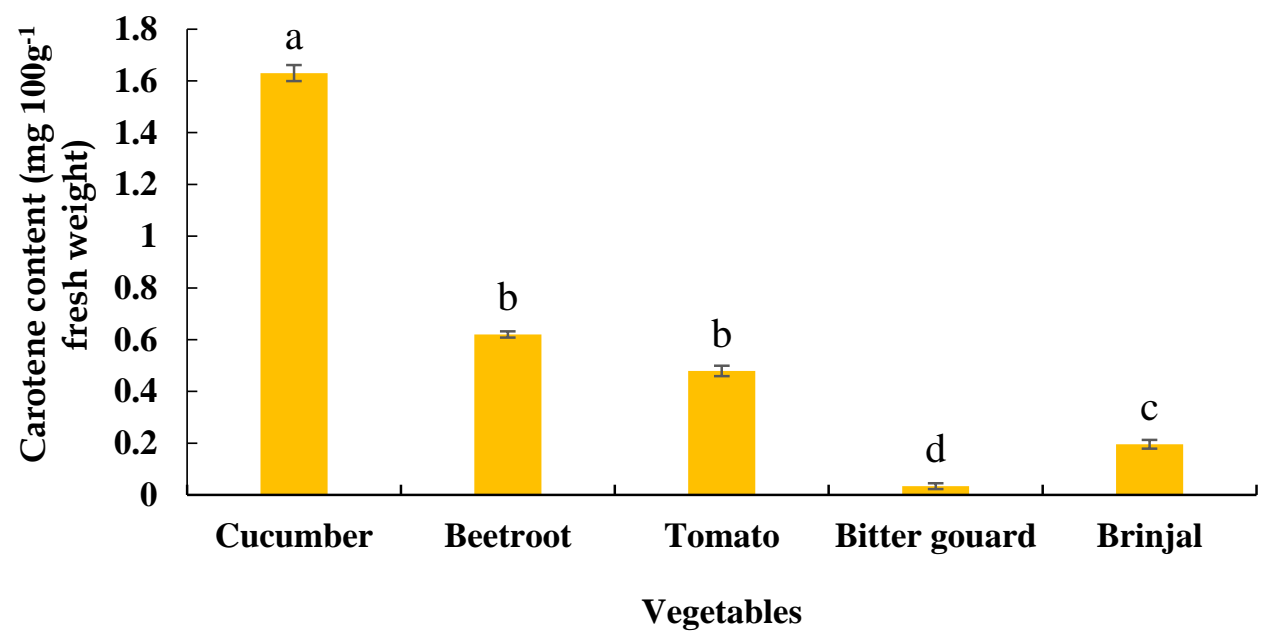

Figure 2. Carotene content of the fresh edible part of some dainty vegetables at maturity stage. The vertical bars represent the mean $\pm S E$ (Standard Error).

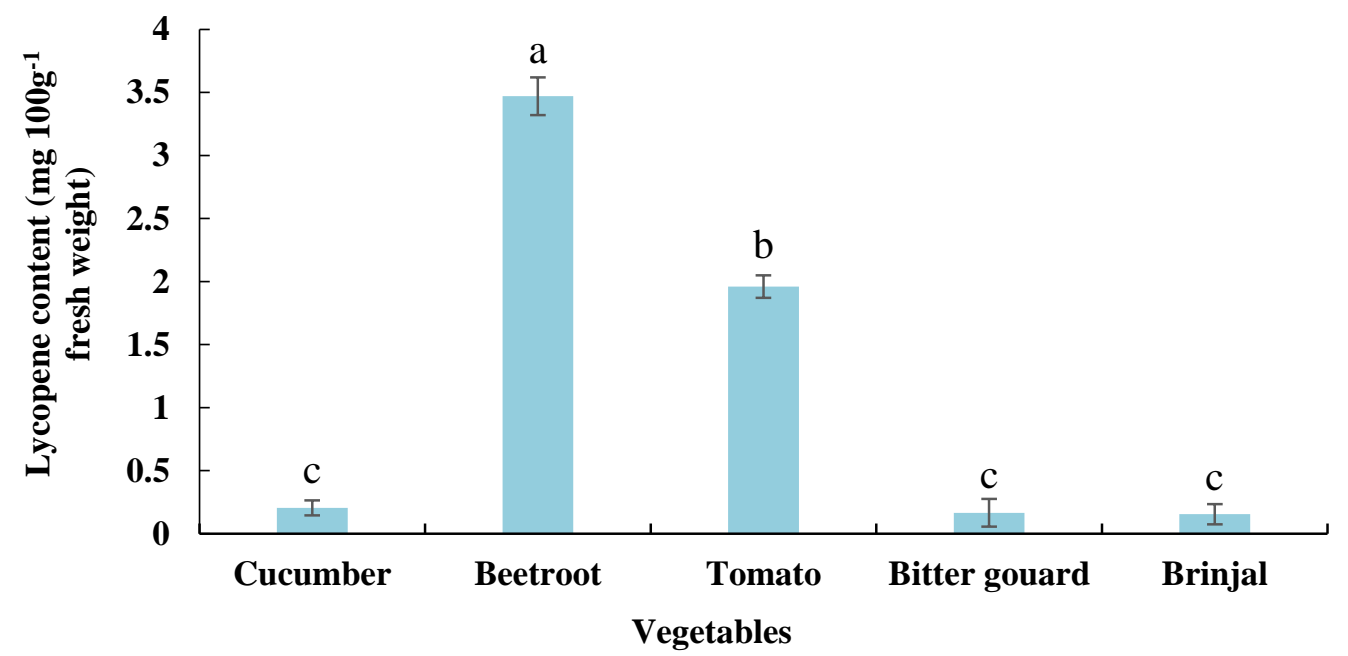

Figure 3. Lycopene content of the fresh edible part of some dainty vegetables at maturity stage. The vertical bars represent the mean $\pm \mathrm{SE}$ (Standard Error).

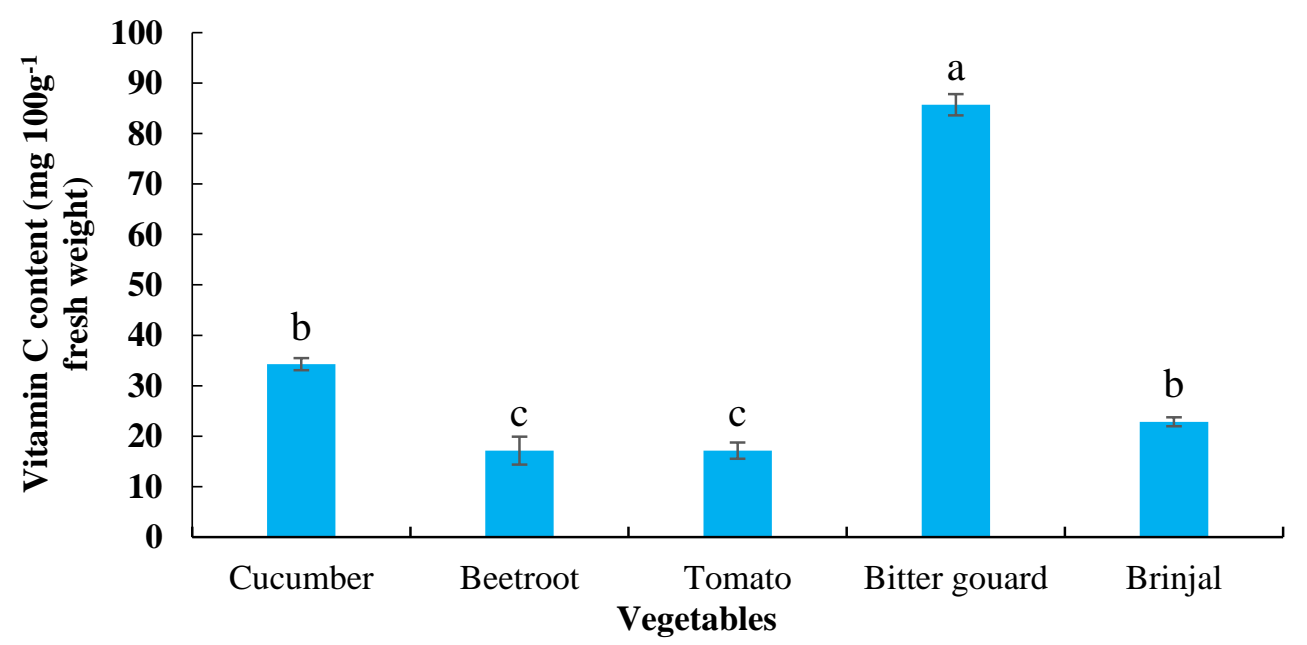

Figure 4. Vitamin $\mathrm{C}$ content of the fresh edible part of some dainty vegetables at maturity stage. The vertical bars represent the mean $\pm \mathrm{SE}$ (Standard Error). 


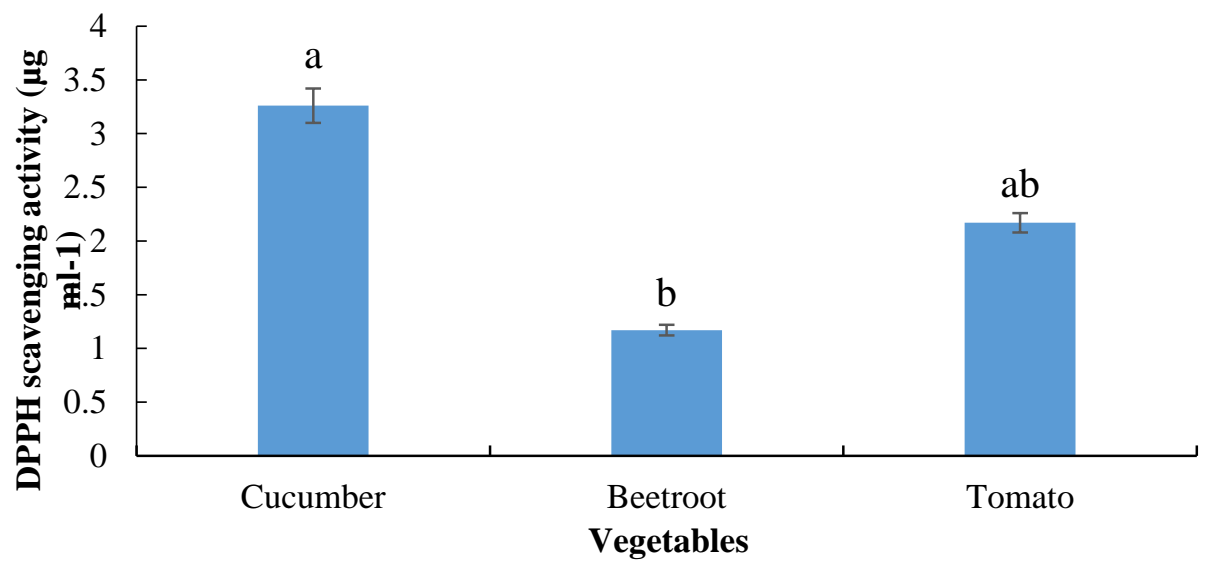

Figure 5. Vitamin $\mathrm{C}$ content of the fresh edible part of some dainty vegetables at maturity stage. The vertical bars represent the $\pm \mathrm{SE}$ (Standard Error).

\section{Discussion}

Antioxidant lobbed chlorophyll (Lanfer-Marquez et al., 2005) is believed to protect the DNA from the hazardous effect of carcinogens (Ferruzzi and Blakeslee, 2007). Chlorophyll also assist in chelation of heavy metals thus reduce heavy metals toxicity (Hosikian et al., 2010) and it deliverers magnesium effectively that helps blood to carry oxygen to the cells and tissues. Antioxidant properties of beta-carotene and lycopene, is believed to protect our body from disease-causing reactive oxygen species and assist to preserve the health of our skin, eyes and immune system (Burri, 1997; Kang et al. 2003). Generally, fresh vegetables are a magnificent source of vitamin C. According to Stratton and Godwin (2011) vitamin C defend our body from the detrimental effects of free radicals. It also helps in prevention of generation of peroxynitrite (ONOO) by scavenging the superoxide $\left(\mathrm{O}_{2}^{-}\right)$ions. Again cold and skin infections are positively cured by vitamin C (Heimer et al., 2009). To treat cardiovascular diseases physicians recommend trinitroglycerin $\left(\mathrm{NO}_{3}\right.$ containing drugs). However, nitrate from vegetables work as a prospective candidate for cardio-protection (Lundberg et al., 2009) without any side effects. Nitrate supports in lowering of blood pressure, improvement of endothelial function and decline in platelet aggregation (Joshipura et al., 1999; Joshipura et al., 2001).

\section{Conclusions}

From the experiment we found the cardio-protective molecule, bioactive compounds and anti-oxidant properties were abundant in tested vegetables. Being natural and cheap they could be better source of nourishment and treat ailment in Bangladesh.

\section{Conflict of interest}

None to declare.

\section{References}

Alarcon-Flores M, R Romero-Gonzalez, JLM Vidal, FJE Gonzalez and AG Frenich, 2014. Monitoring of phytochemicals in fresh and fresh-cut vegetables: a comparison. Food Chem., 142: 392-399.

Alissa EM and GA Ferns, 2017. Dietary fruits and vegetables and cardiovascular diseases risk. Crit. Rev. Food Sci. Nutr., 57: 1950-1962.

Barros L, AM Carvalho, JS Morais and ICFR Ferreria, 2010. Strawberry-tree, blackthorn and rose fruits: detailed characterization in nutrients and phytochemicals with antioxidant properties. Food Chem., 120: 247254.

Burri BJ, 1997. Beta carotene and human health: A review of current research. Nutr. Res., 17(3): 547-580.

Ferruzzi MG and J Blakeslee, 2007. Digestion, absorption and cancer preventive activity of dietary chlorophyll derivatives. Nutr. Res., 27: 1-12.

Heimer KA, AM Hart, LG Martin and S Rubio-Wallace, 2009. Examining the evidence for the use of vitamin C in the prophylaxis and treatment of the common cold. J. Am. Acad. Nurse. Pract., 21: 295-300.

Hosikian A, S Lim, R Halim and MK Danquah, 2010. Chlorophyll extraction from micro algae: A review on the process engineering aspects. Int. J. Chem. Eng., 1-11 
Joshipura KJ, A Ascherio, JE Manson, MJ Stampfer, EB Rimm, FE Speizer, CH Hennekens, D Spiegelman and WC Willett, 1999. Fruit and vegetable intake in relation to risk of ischemic stroke. JAMA, 282: 12331239.

Joshipura KJ, FB Hu, JE Manson, MJ Stampfer, EB Rimm, FE Speizer, G Colditz, A Ascherio, B Rosner, D Spiegelman and WC Willett, 2001. The effect of fruit and vegetable intake on risk for coronary heart disease. Ann. Intern. Med., 134: 1106-1114.

Kang KD, IS Kim, CH Cho, H Yim and HS Kim, 2003. Use of lycopene, an antioxidant carotenoids in laying hens for egg yolk pigmentation. Asian-Australas J. Anim. Sci., 16: 1799-1803.

Lanfer-Marquz UM, RMC Barros and P Sinnecker, 2005. Antioxidant activity of chlorophylls and their derivative. Food Res. Int., 38: 885-891.

Lundberg JO, MT Gladwin, A Ahluwalia, N Benjamin, NS Bryan, A Butler, P Cabrales, A Fago, M Feelisch and PC Ford, 2009. Nitrate and nitrite in biology, nutrition and therapeutics. Nat. Chem. Biol., 5: 865-869.

Mamun AM, N Rumana, K Pervin, MC Azad, N Shahana and SR Choudhury. 2016. Emerging burden of cardiovascular diseases in Bangladesh. J. Atheroscler. Thromb., 23: 365-375.

Sakil MA, MAS Polash, M Tahjib-Ul-Arif, MA Hossain and MA Hossain, 2018. Cardioprotective molecule and bio-active compounds of some selected vegetables available in Bangladesh. J. Bangladesh Agril. Univ., 16: 82-87.

Miller DD and RM Welch, 2013. Food system strategies for preventing micronutrients malnutrition. Food Policy., 42:115-128.

Polash MAS, MA Sakil and MA Hossain, 2018. Post-harvest biodegradation of bioactive substances and antioxidant activity in microgreens. J. Bangladesh Agril. Univ., 16: 250-253.

Polash MAS, MA Sakil, S Shahida and MA Hossain, 2019. Selection of suitable growing media and nutritional assessment of emerging fresh produce-microgreens (Accepted Paper in Agri. Res. J.)

Sanja SD, NR Sheth, NK Patel, D Patel and B Patel, 2009. Characterization and evaluation of antioxidant activity of Portulaca oleraceae. Int. J. Pharm. Sci., 1: 74-84.

Stratton $\mathbf{J}$ and $\mathbf{M}$ Godwin, 2011. The effect of supplemental vitamins and minerals on the development of prostate cancer: a systematic review and meta-analysis. Family pract., 28: 243-252.

WHO 2005. Fruit and vegetables for health: report of Joint FAO/WHO Workshop, 1-3 September, 2004, Kobe, Japan.

Xiao Z, GE Lester, Y Luo and Q Wang, 2012. Assessment of vitamin and carotenoid concentrations of emerging food products: Edible microgreens. J. Agric. Food Chem., 60: 7644-7651.

Xiao Z, GE Lester, E Park, RA Saftner, Y Luo and Q Wang, 2015b. Evaluation and correlation of sensory attributes and chemical compositions of emerging fresh produce: Microgreens. Postharvest Biol. Technol., 110: $140-148$. 